\title{
Sustainable Urban Property Development and Neighbourhood Dynamics
}

\author{
Tom Kauko*
}

Department of Geography, NTNU, Norway

\begin{abstract}
Concerns about the sustainability of urban property development are increasing amid broader concerns of sustainable development and contemporary financial crisis. Central to the sustainability agenda are the physical, economic, social, and cultural features of the built environment, together with various institutional parameters therein. This is a review article on property development and neighbourhood dynamics with focus on three interlinked issues: property, neighbourhood and - as a category at the interface of these two topics - urban regeneration; and lastly, about methods and methodology to study such phenomena. The common denominator for these issues here is the location (urban renewal areas, neighbourhoods) in relation to property prices. The paper concludes with a suggestion for a .methodology to evaluate the sustainability of area-level property development activity.
\end{abstract}

Keywords: Neighbourhood, property development, sustainability, urban regeneration.

\section{INTRODUCTION}

The sustainable development agenda is increasingly dominating urban policy and planning discourses. Such is the extent of this agenda that even the traditionally businesseconomics dominated real estate field has become influenced. In many urban areas real estate investments are now considered in a more sustainable framework because a sustainable place generates a competitive advantage over unsustainable places. This is about long-term processes, in three dimensions: environmental (i.e. physical), social and/or economic. The possibility, feasibility and necessity for either new development or refurbishment of the building stock depends on the character of the area within the city, the city itself, and the institutional setting where investment takes place.

How sustainable then is urban property development and neighbourhood revitalisation? How does any sustainability or unsustainability arise? This literature review sets out to explore these two questions. A further aim is to design an analytical framework and methodological approach for the evaluation of property development activity at the area-level as to the extent to which it is to be considered sustainable, and what the plausible explanations for this are. This conceptualisation contains a number of more specific issues:

- Whether (or not) the market for residential or business units and floor-space is driven by demand side considerations.

- The role of tenure change - ostensibly, on the residential side the tendency is from renting to ownership whereas the opposite tends to be true for the commercial side.

- $\quad$ Given that no demand driven process takes place, the extent to which the motive of the developer and

*Address correspondence to this author at the Department of Geography, NTNU, Universitetssenter Dragvoll, NO-7491, Trondheim, Norway; Tel: 73591919; E-mail: tom.kauko@svt.ntnu.no investor (including the local government) for a supply increase includes sustainability or just green considerations.

- Whether the availability of subsidies impacts the decisions being made.

At the core of this thinking is an assumption about social and physical changes taking place in the built environment. Most of the literature in this research area constitute quantitative assessments of a resulting or hypothetical land use change and whether a certain design involving infill and consolidation is in par with the preferences of housing consumers $[1,2]$.

This is a rich problem area, and there is no clear consensus about how to formally treat it within empirical research. This is why the focus of this contribution towards the end shifts from the objective: property development and neighbourhood, to research methodology. The text is organised around three main topics in the following order: first property development; next, neighbourhood change; and after that - as a fusion of the previous topics - area-based revitalisation. In the last module the methodological proposition is set out.

\section{THE DRIVERS OF URBAN PROPERTY DEVELOP- MENT}

\section{Market Value and Government Interventions}

In the midst of all enthusiasm towards 'culturalist' approaches and 'soft' factors it must be kept in mind that the role of the economy and market processes is paramount, and therefore needs to be respected in a review on property development and broader, physical urban change. In real estate economic theory (which mostly follows the neoclassical tradition, although other lines occasionally are recognised), the common assumption is that developments in attractiveness (often approximated through transaction price of owner-occupied dwellings) and provision of new supply tend to be associated spatially and temporally. In other words, in an urban property development context the local 


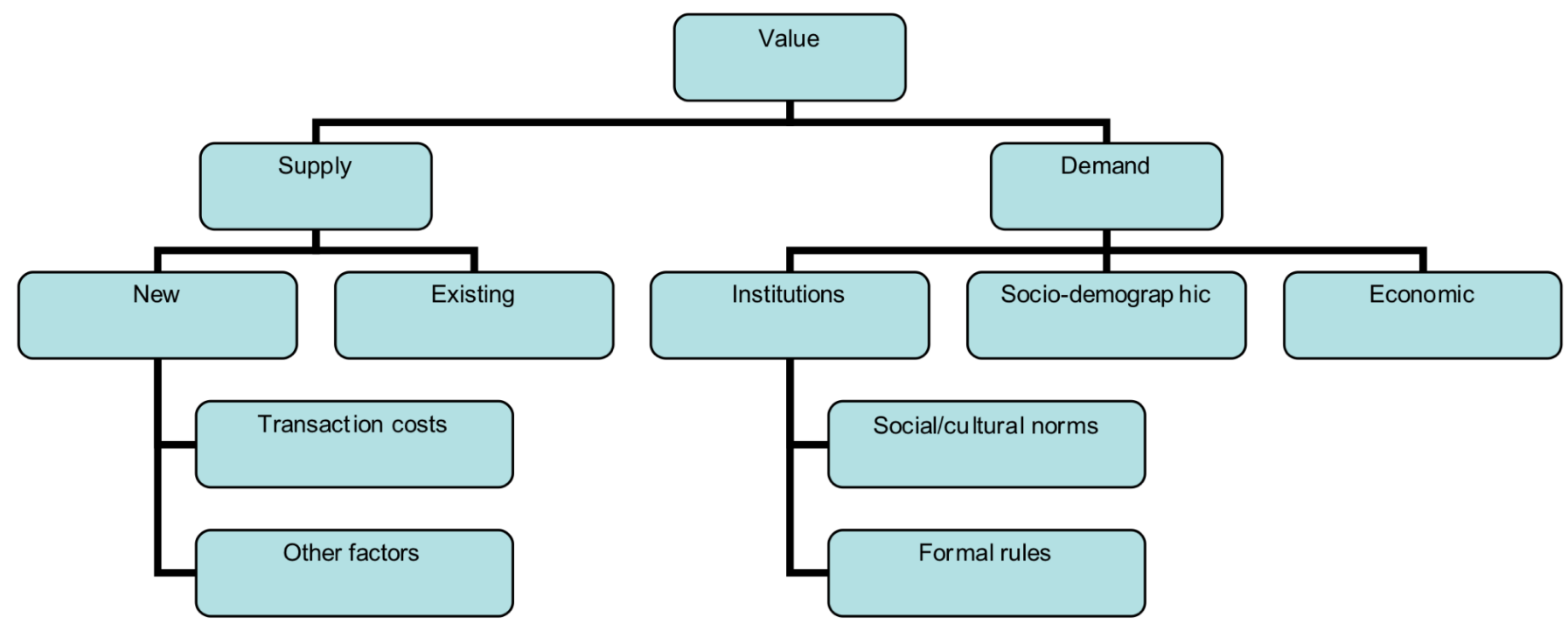

Fig. (1). The price formation of real estate at a specific location.

property price development may be seen as a by-product of the provision of the built environment, and thereby, ideally, makes a convenient indicator of relative attractiveness of an area. Here three possible general effects are relevant to understand. First, whether the planning regulations together with other factors contribute to the production of residential and office space by either stimulating, facilitating or impeding it. Second, whether this new supply together with changes in the existing stock, including refurbished dwellings and buildings, contribute to a supply increase of floor-space. Third, whether - and how - this supply increase together with the determinants of demand, notably conversions from rental occupancy to ownership, contribute to a change in property prices. Fig. (1) shows the breakdown of these processes affecting price formation.

Real estate, like design and architecture, comprise a group of specialised producer services [3]. In other words, the real estate industry covers both the production process and the social setting of services; therefore supply and demand aspects must be balanced. While the short-term price formation mechanism is demand driven, what perhaps is more difficult to see is that also the producer preferences matter and here the issue is about the supply side driver long-term goals and motivations of developers, investors, planners and other relevant decision makers [4].

Amidst the discussion on various kinds of effects, the role of business economics will continue to be the key to viable housing developments, and should never be underrated. To give an example, Gyorko and Saiz [5] conclude that the impact of supply-side on reinvestment in housing (in the US) is meaningful, and that the supply-side dynamics determines the profitability. In such a mode of analysis institutions are usually handled implicitly by controlling for a shift in functions if different markets or points in time are included within the sample. A more explicit variant of the same theme is the comparative statics framework, most notably in studies on zoning and planning effects. Then we have obtained a 'pseudo' type of way to deal with institutions, which seems methodologically sound at first sight. If the analysis is conducted properly, that is, there is enough data of good quality and the model specification is correct, then a positive or negative price association should be captured with an on/off-effect of the regulation variable of interest. Obviously, institutions are defined somewhat narrowly in these studies, but their very existence is indeed acknowledged and theoretically well specified.

If the time aspect is included in an ex-post evaluation setting, and the effect of all relevant fundamental variables controlled for, one obtains ideal conditions for isolating and measuring the capitalisation of local public investments and environmental improvements, as well as effects of planning constraints and other institutional factors [6]. This type of analysis can be used with cross-sectional data as well, if a sufficient variation of different (planning) regimes is captured. In fact, using this technique both temporal and spatial dynamics in locational value factors may be captured. Hence the analysis might be seen as "mainstream economic analysis with institutional variables" as opposed to "institutional analysis proper". These methods and techniques of empirical research focus on a snapshot at a given point in time, with variance across a spatially defined context; then the institutional or behavioural element may be captured with inclusion of territorially defined regimes $[7$, 8].

Guy and Henneberry [9] focus on behavioural factors of socio-cultural, psychological and economic-rational kinds in an attempt to integrate social and economic processes into urban development processes. They argue that, in order to better understand the complexity of decisions involved, a more open and interdisciplinary analysis would serve well. In much similar spirit, Doak and Karadimitriou [10] offer an attempt to provide an operational guideline and starting point for analysis on the complexity and networks involved in redevelopment. What kinds of factors steer the price formation and the development processes beyond considerations about economic profitability calculations? These authors see urban redevelopment as a complex sociospatial process involving actor networks, and suggest that non economic factors have a role to play for the structuring of the market. In this context the meaning of the demand side institutions needs some elaboration (see Fig. 1). The social 
or cultural norms concern the user and tenant considerations; more specifically, the quality of life (QOL) of the people occupying the dwellings or offices and their daily living environment. The formal rules here pertain to various financial incentives for sustainable building.

Today the attention has shifted from a simple marketgovernment dichotomy to a situation of two competing ideals. One is about cooperation between a private sector which looks for new investment opportunities and a public sector which needs funds. These two main groups of actors have skills in different areas - corporations and firms are accustomed to risk taking and quality control, whereas the government is experienced in project management and infrastructure provision. The other ideal is about forming alliances in which civil society takes part. In both cases the goal is to reach a system of appropriate long-term win-win situations.

Probably in most countries of the world, some form of cooperation contract between public and private sector actors has become more important in recent years. The way such a "community governance" structure is set up, however, varies greatly, even in Europe: notably, public-private partnership (PPP) is common in many cases in Central Europe, whereas the participation of the voluntary sector is widespread in Nordic Europe.

\section{Balancing the Drivers}

It is often claimed that 'post-Fordist' times have witnessed a substantial diversification of preferences and a fragmentation of the markets [11]. This has redirected the research efforts away from general (neoclassical) economic models towards more particular models about the drivers of property development and market activity.

When the demand for housing drives prices and profitability up, the sale takes place either before or after an actual dwelling improvement or an upgrading of the environment. The price increase comprises two elements: (1) changes in actual quality - amenities as well as transportation; (2) speculative changes in market value based on future price expectations and without changes in actual quality $[12,13]$. (A more profound coverage is provided in the next section.) It may be that house-buying opportunities arise from an inefficient market (i.e. case 2 above). This in turn would generate an incentive for improving the physical structures later; however, sometimes the causality is the opposite: an actual upgrading of the environment is reflected in the market price (i.e. case 1 above). Therefore, the challenge of sustainability enthusiasts is not only to incorporate 'healthy' elements to this upgrading, but also to test this design solution at the market-place.

Bryson and Lombardi [4] maintain that, while possibly increasing the initial costs, applying sustainability criteria can have added benefits in terms of product differentiation, attracting tenants and investors with social responsibility agendas, reducing long-term running costs, negotiations over sites and potential long-term value enhancement of the investment. The double bottom line comprises interplay between 'profitability' and a value system constructed around 'sustainability' (social, economic and environmental) of the company's developments. This strategy is furthermore "self-imposed by the company and reflects the interest, experience, motivations and visions of the firm's management team". In their qualitative study based on indepth interviews, participant observations and document analysis Bryson and Lombardi investigate how two UK based developers, namely ISIS Waterside Regenerations and $I G L O O$, attempt to trade of financial objectives with a broader sustainability agenda, when it is assumed that ".. a type of balancing activity that is common amongst social economy enterprises is being incorporated into some privatesector business models". The conclusion is that because these 'alternative' development companies are pro-active in the tendering process they have managed to out-compete mainstream developers on reputation and product rather than on price. Being proactive has gained market advantage by integrating sustainability into the business models.

Insofar as only profit is considered in the development of housing, the project is unfeasible in the long run. Indeed, the demand-side motives intuitively cover the use value as the prospective owner-occupier is supposed to live in their dwellings themselves, although, here the level of sustainable investment is arguably an issue of education of attitudes. However, for the supply-side there is a crucial difference between only-for-profit motives and motives where normal profits are reaped and the remaining margins are fed back to the use value of the project: either to secure a high quality of the development itself, or to spend on the environmental and social values of the location in terms of amenities and public services. For example, if the viability of a given development project allows it is possible to include a share of affordable housing and still obtain positive residual development values of the project for various residential development options and parameters [14]. However, affordable housing may be seen as a 'bad' and thereby an unsustainable case, as argued by some analysts.

To summarise, economic analysis of aggregate markets, individual benefits and regulation of market behaviour is the only valid starting point when we aim at analysing prices, QOL and built environment provision, and this goes for both homes and office-space alike. On the other hand, today cooperation and governance much dominate the discourse. Moreover, the motives of each actor are of four kinds: supply- or demand-driven; and within each category, either profitability- or sustainability-driven. This framework is the key to explaining the property development processes in an urban context. How we then achieve sustainability depends on the particular balance of these elements - the more sustainable ones being biased towards the demand-side drivers. When the scale of this analysis is broadened spatially, two kinds of changes in the neighbourhood structure are noteworthy: first, changes in area attractiveness that stem from organic market effects; and second, manifestations of new supply in relation to the plan that stems from possible urban policy effects. The next section lists the most important influences of the former type, while the latter type of influence will be discussed in the section that follows.

\section{NEIGHBOURHOOD ATTRACTIVENESS}

\section{Market-Based and Socio-Demographic Effects}

Insofar as the analysis concerns the neighbourhood level, the supply factors - i.e. the more rigid supply/production 
aspects - tend to carry more weight than the demand factors - i.e. the more shifting demand/consumption aspects, [15]. On the other hand, the choices made in the housing market are shaped in powerful ways by the choices of others, which indicate a community wide effect [16]. Furthermore, these influences may, to a varying degree, be consistent with particular sustainable urban development agendas. Ferrari and Lee [17] suggest that, as the tendency is for affluent households to move out of cities, housing has a potential function for reversing such unfavourable migration trends. As a short-term strategy housing investment is often related to the economy, but Ferrari and Lee make a case for a longterm analysis as well. The other often expressed concern here is about the empirical research agenda not being sufficiently nuanced $[18,19]$.

The influence of the socio-demographic composition of the demand for housing is increasing in importance, and so too has this research topic received plenty of attention recently in various contributions. In one way or another, these address direct problems related to security concerns triggered by ethnic and socio-economic groups that are perceived as threats, and indirect problems pertaining to the social exclusion and segregation of such groups. This is the classic issue about negative externalities. Barber, Groves and Murie [20] observe that ethnic segregation in UK is, due to weaker government intervention, stronger than in most/all Continental European countries, but still weaker than in US. However, they argue that the main reason for the UK segregation patterns, at least those observed in Birmingham during the 1950s and 60s is not an effect of the weak welfare state, but rather the effect of building council housing. This is because, by excluding ethnic minorities from council housing in the past, strong segregation occurred between white working class areas and areas without council housing where the ethnic minorities had to settle. One sector was promoted at the expense of excluding others. ${ }^{1}$

Popkin [21] looks at how a transformation of traditional public housing in the USA is under way. Today federal policy is replacing distressed housing with mixed-income developments, and also dispersing very low-income tenants throughout the metropolitan area. Popkin emphasises the role of racial segregation in the neighbourhoods in generating lower property values, weaker schools, a higher crime rate, and a lower public service level. In much similar vein, concerns about the detrimental effect of nearby situated affordable housing on property values have been aired by Nguyen [22]. On the other hand, empirical evidence indicates how the poverty is inevitably shifted from the indemand inner city towards the suburbs [16]. Goodwin [23], however, finds black communities as active and innovative contributors of the city building process, and not only as passive victims of urban decay.

Given that the recent (i.e. after 9-11) stigmatisation of Muslims in western urban society in general is capitalised into negative neighbourhood effects, Smets and Kreuk [24] evaluate intra- and interethnic contacts between residents in an ethnic neighbourhood in western Amsterdam. Based on

\footnotetext{
${ }^{1}$ It can be argued that this is not completely true anymore as the West Indian community has now become highly associated with public housing in some UK cities.
}

the interviews of Turks - the most segregated ethnic group in the Netherlands - and 'natives' they find that the latter tend to avoid ethnic minorities because of reasons such as the presumed increased rubbish and disarray on the streets ( $p$. 43). Nevertheless, the overall findings of this study indicate that "... interethnic contacts between natives and Turks are more dynamic and diverse than assumed in the integration debate" (p. 47).

Based on their evidence from Utrecht, fourth largest city in the Netherlands, and one with substantial socio-spatial exclusion problems, Permentier, Van Ham and Bolt [25] conclude that the socioeconomic and ethnic mixture determines the reputation of a neighbourhood, which in turn affects its ability to attract the 'right type' of new residents.

\section{Socially Inflicted Demand}

The so-called 'softer' factors relating to identity and lifestyles are in principal subordinated to the 'harder ones' that originate in broader economic forces and population movements. However, it is - with increasing frequency claimed that urban dwelling consumption depends partially on urban lifestyles and identities, as well as images created by the developers who market the project [26]. This builds on Ley's [27] findings about a 'pro-urban ethos' in Canadian cities, and links to the character of the marketplace and the decision of marketing strategies. In his discussion on segregation, Robinson [28] emphasises 'place' as a determinant of residential preferences of ethnic minorities, insofar as the benefit of familiarity has to be weighed against perceived threats of moving to an alternative location.

Based on research concerning Denmark, Gram-Hanssen and Bech-Danielsen [29] concluded that, for 'the house' to be understood as 'the home', the activity and the relations of the residents matter, possibly being linked with identity. There are many variations in what is considered the most important: the feeling of attachment to the neighbourhood being one of them. In this way the house may be linked with identity, which fits with the theory on the communicative aspects of consumption, as opposed to the functional aspects of consumption.

Ærø [30] puts forward a first attempt to code lifestyle in terms of work, home and neighbourhood background, using a quantitative stated preferences approach - although usually socio-cultural factors are investigated using qualitative approaches. While Ærø's study as such confirms old sociodemographic theories that emphasise the life-course of households, it also introduces new aspects related to lifestyle and the familiarity aspect in particular. These results resonate with Bourdieu's [31] theory of cultural capital. However, despite an intuitive appeal, the 'culturalist approach' has unavoidable limitations when studying concrete and constrained phenomena such as sustainable property and urban development.

The discussion of neighbourhood requires a differentiation in terms of a number of aspects; this may, for example, be about the production of building materials: in order to minimise the costs, large volumes of prefab housing were built throughout the 1960s and 1970s; today these are 
considered undesirable in most of Europe. ${ }^{2}$ For example, in Budapest, Hungary a variety of prefab housing estates exist, and their quality and price range largely depend on the era they were built. Furthermore, in the same city, today the gated communities are becoming increasingly popular for the upper and middle class households, but here too the range in quality and price is wide; lots of factors matter besides building materials such as the image and whether there is a market failure due to excess supply or demand. Speculative local housing market behaviour is one of these factors. However, there are two different types of speculative behaviour in relation to neighbourhood upgrading. One is forward looking: future quality improvements, usually a belief that active policy implementation saves an unfavourable area. The other is backward looking: using historical market data, and concluding that 'organic' change (i.e. traditional gentrification) will take place in 'an area with potential,' thereby fulfilling this potential [32].

\section{Gentrification}

Here it is fair to note a parallel research tradition: it is argued that the New Economy has had influences on the demand - and to a high degree on the gentrification processes taking place in cities that rely on knowledge intensive industries [33]. According to Hamnett [34] the globalisation has led to professionalisation, and a growing middle-class, which in turn has generated a shortage of good quality housing near city, and eventually gentrification. To give a few recent samples of this discussion, Beider [35] concludes that gentrification is both good and bad: on one hand it destroys social relations, but on the other hand given a local property tax regime - it increases the tax revenue that could help in diverging from a potentially unfavourable trajectory of neighbourhood development. Smith and Butler [36] conclude that gentrification, while a global phenomenon perhaps, is also a phenomenon that shows vastly different expressions and trajectories across cities and also differences within areas in one and the same city. Further, many overlapping subcategories of gentrifiers have emerged, and these are possible to recognise in terms of their socio-demographic background as well as motives amidst the fragmentation of 'the urban middle class' - this is also the message of Butler [37].

To give a concrete example of a gentrification study carried out in this spirit, Bounds and Morris [38] analyse the 'second wave' gentrification in inner-city Sydney, Australia. They concluded that it was large-scale in nature, led by private developers, further stimulated by the state, and leading to minimal displacement of the original residents. Thus not the problematic kind of gentrification termed the 'first wave' that was led by owner-occupiers and was likely to cause conflicts. When these findings are put in a broader context, the gentrification appears as a diverse economic and cultural phenomenon. Furthermore, no hegemonic model exists for the mechanism of gentrification, which may, like in Sidney, be the result of an active redevelopment strategy; and does not necessarily have to experience displacement problems. When the government leadership grows further it

${ }^{2}$ Although it is to observe that this is not necessary the case in the Mediterranean or Post-communist countries. is sometimes referred to as 'third wave' (or government/state-led) gentrification [39].

Whatever one's stance towards the phenomenon itself, gentrification research offers a handy guideline for looking at quality changes in a neighbourhood. It is therefore rather surprising that, while a plethora of empirical research on gentrified neighbourhoods has been carried out in the last $c a$. forty years, not much of it is based on measurable indicators about housing and social features. Sullivan's [40] statistical analysis on two gentrified neighbourhoods in Portland, Oregon, therefore is worth mentioning: he finds out that, despite rent increases, also the original inhabitants of gentrified neighbourhoods approve of the changes taking place (even if they are renters), because the neighbourhood quality is improved.

Adding micro-location and the spatial element to the market economic, behavioural and institutional drivers of urban property development covered thus far directs the attention of the analysis towards an elusive set of features of the built environment. These comprise spatial patterns manifested as a result of the socioeconomic and demographic compositions, and socio-cultural categorical 'acquired tastes'. These explanations may overlap in a given place and time. Gentrification is perhaps the best example of a multiple and context dependent phenomenon with several overlapping explanations. After this discussion on market driven changes, the next discussion pertains to policy driven changes aimed at improving the quality or liveability of the neighbourhood.

\section{SUSTAINABLE REHABILITATION OF URBAN HOUSING AREAS}

Urban policy may have an impact on the type - and thereby sustainability - of the development that takes place. A rehabilitation program is defined for this study as all kinds of targeted active or passive government effort to bring about a physical, economic and/or social change in an urban area. It can be predominantly private (i.e. traditionally biased towards profitability) or public (traditionally geared towards social and environmental goals); and either more supply or demand driven, as already was discussed in the section on the drivers of property development. It includes both large scale urban renewal as well as piece-meal rehabilitation of buildings, and can be more comprehensive or more fragmented in nature. The contextual element of urban rehabilitation is different in each city, and also largely different in each neighbourhood within one and the same city, as the section on neighbourhood attractiveness suggested. It can involve direct physical measures such as expropriation and zoning regulations, as well as more indirect measures, such as mixing of ownership and rental housing, development of housing finance vehicles and subsidy schemes.

Plenty of critical comments address the way urban renewal has been carried out. Meen and Andrew [41] point out that in Britain - like elsewhere in Europe - the deprivation rankings of urban areas have changed only little despite ten years of implemented regeneration policies. Lees [42] criticises the current policy and academic discourse in UK and US, where both context and temporality is sidelined. Couch [43] notes how in the Liverpool context of urban 
renewal the local government and planning role was weak and that the role of state, private and grassroots activity was strong. Based on comparison at a European level Couch [44] also notes that what matters for successful urban regeneration is determined by whether the city is situated in the periphery or not, the level of private and public services in the particular location within the city-region and the success of marketing based on image creation. Furthermore, a realisable potential for urban regeneration depends on a healthy state of the regional economy and lack of competitor projects, as well as location and physical form.

Stead and Hoppenbrouwer [45] compare two countries with respect to the same urban vitality policies implemented: in the Netherlands, the reasons for them were primarily spatial, whereas in England the reasons were environmental, economic and social. To give an example of the social aspect, Weingaertner and Barber [46] assert that, for a successful retention of old indigenous businesses, and thereby fulfilling one neglected aspect of sustainability of urban regeneration, it is not only important with a location in the city core, but the city identity matters too.

Turcu [47] deals with a specific aspect of social sustainability of urban regeneration termed sustainable communities. Due to its intangible nature, Turcu notes that it may not be feasible to try to be 'over-precise' in the definition of 'community sustainability.' Because theory suggests context dependence here, she argues that specific regeneration initiatives are needed to maintain community sustainability including housing affordability. However, the findings from Turcu's study suggest that housing market renewal across different English regions is dominated by an economic rather than social agenda. In fact, affordability could be defined as a subgroup of the generic category of 'economic' (rather than 'social') sustainability [48, 49].

In an earlier section PPP was brought up as one possible solution to initiate urban development projects. In a comparison between two urban renewal projects, Taşan-Kok [50] shows how the Kop van Zuid project in Rotterdam offered good opportunities for private property investment although it was developed mainly on public land whereas its Antwerp counterpart, the Het Eilandje project, could only attract investment in a fragmented way due to the less advanced and internationalised property investment and development sector in Belgium than in the Netherlands. The Antwerp case suffered from sporadic and opportunistic private-sector participation caused by a lack of transparency in the plans of the port authority. On the other hand the social transformation of this area was considerably smoother than that of Rotterdam, where the project resulted in an elitist and isolated new residential area. That neither of the projects could escape some kind of problems with the implementation shows how difficult it is to determine the ideal PPP structure for a given project.

Van Beckhoven and van Kempen [51] evaluate the effect of social and economic vitalisation of the city in Amsterdam and Utrecht in the Netherlands. They conclude that the neighbourhood does not play a substantial part in the life of residents, and that, therefore, any idea of urban restructuring having a positive influence, in this sense, must be treated with caution. Elsewhere, similarly ambivalent evidence from Hoogvliet, a peripheral Rotterdam area shows how, after restructuring, the long-term stayers perceive the neighbourhood as more 'liveable' on one hand, but more socially problematic on the other [52]. Thus, based on Dutch evidence it is ambiguous to claim that urban renewal would, on balance, be beneficial for the local community.

Kucharska-Stasiak and Zaleczna [53] carry out a case study of Lodz. This is an otherwise typical $19^{\text {th }}$ century Polish industrial city, but one that survived the war, and because of that possesses narrow streets and an old building stock. This impedes further development. They conclude that municipality is not a capable manager of their property stock, and that problems are used for political reasons.

According to Schmidt [54] a system for environmental certification and housing quality ought to be developed in order to secure consumer choices at the housing market. She points out that while a proactive housing policy might improve the quality of housing and communal areas it is not a guarantee for such quality control. This being in a Norwegian context, the issues at stake here relate to the link between QOL and density regulations in plans.

Here it is important to note that the processes and goals of the urban rehabilitation are tied to the local conditions. For example, how easy is it really for (Continental) Europeans to understand the North American discourse of New urbanism [55, 56], or even the British discourse of Urban renaissance, as the difference in urban context is substantial [41]? Yet these concepts, New urbanism (or Neotraditionalism) and Urban renaissance, mean largely the same thing: regeneration of inner city and other declining neighbourhoods [57]. ${ }^{3}$ The former set of design principles were devised in the US during the late 90 s, and have become proclaimed since the year 2000. For the latter policy, Atkinson [59] considers Britain's Urban renaissance an unjust 'design-led approach to promote 'liveability' and recapturing middle-class households" - this is also the gist of the discussion by Schwegler [60] concerning the CEE circumstances.

Arctander [61] finds that in the Norwegian Brownfield and waterfront developments it is the private development companies who carry out the planning and implementation, and that this gives the developer considerable powers on how the design of working and living environments will be implemented.

Lastly, more market influence in urban regeneration does not necessarily result in better designed neighbourhoods, as the case of the European quarters in Brussels shows. Issues such as consulting existing residents, incentives towards sustainability offered by the public sector and community cohesion are also vital for the success of a project that is planned as sustainable. Thus a sustainable cost-benefit analysis (i.e. extended cost and benefits are included, beyond economic short-term effects) allowing for welfare effects is required here. Besides this, urban renewal must be accommodated for in legislation as well as European level

\footnotetext{
${ }^{3}$ In Canada, New urbanism and infilling the core areas with mixed uses is apparently better integrated into the planning practice than in USA [55]. Southworth [58] criticises the piecemeal efforts of Neo-traditional design, and relegates it to suburbia; Deitrick and Ellis [56] however consider New urbanism successful for inner city revitalising efforts using financial, functional and aesthetic criteria.
} 
policymaking. This is because sustainable urban regeneration is about the creation of liveable cities and neighbourhoods, a vibrant mixed use and the reduction of car use, on top of the property development aspect [62].

\section{A JUSTIFIABLE METHODOLOGICAL APPROACH}

There is no guarantee that a particular management structure will ever lead to sustainable urban development. Neither is increased market influence such a guarantee. In fact, this is a strongly context dependent exercise - and one that lacks a recipe. Nevertheless, some weak form determinism is possible here; as asserted throughout the text, the sustainability balance of urban regeneration projects is an empirical issue dependent on particular institutional market circumstances. These circumstances vary, and tend to change, and furthermore the criteria to assess these circumstances vary and may change too [63]. Case studies on neighbourhoods that are undergoing substantial rehabilitation highlight the relationships between urban consolidation, the local housing market, and the residential quality at a micro-level in a dynamic context. To carry out such rigorous analysis, we need an analytic framework, and methodology for evaluating the sustainability of property developments at the area-level.

The choice of method is today not only an issue of technique (ex-post or ex-ante; monetary or multi-criteria etc.) but also one of recognising power imbalances within the processes and programmes subject to evaluation in a situation where the researcher cannot easily take distance from the study objective. In other words, how well is one able to see the situation from a 'bird's eye view'? Following Sager, Hull [63] argues that planning is too slow for evolving policy contexts, and that, as a consequence, the traditional forms of cost-benefit analysis are being replaced by other methods that recognise involvement and participation. Hull (p. 199) concludes that the close contacts between the research community and decision makers, established through contract research, come with a price of compromised autonomy, validity and pursuit of knowledge for its own sake.

In order to study urban regeneration in relation to real estate and housing development, the jungle of concepts, mechanisms and processes presented thus far needs to be simplified. The supply and demand side analyses can be broken down as shown in Table 1. This setting is based on empirical research and indicates that many different aspects can be related to many different methods - and that this issue applies for both demand and supply side analysis (i.e. the whole Fig. 1). The focus of the investigation is what has happened in a given place and time, and against the social background of a given area. The empirical indicator of this is the change in prices, when associated with other kinds of qualitative and quantitative changes in the built environment. Theoretically, a positive price change may not be related to tangible quality improvements, but in some way has resulted from a government effort to either actively 'fuel' or more passively 'facilitate' urban renewal in the area. Therefore, what has occurred in given locations should be compared to the corresponding occurrences in a wider area or the whole city. The main hypothesis here is that when demand increases for a housing unit, the value, that is, the reservation price of the owner and buyers, increases too. Here an important conceptual clarification is in place: not only the quantity demanded increases, but also the value of each demanded unit increases as a result of supply-demand interplay. It can furthermore be noted that both the supplyand demand-driven marketplaces can be healthy or distorted to various degrees, which needs to be taken into account when commenting on the sustainability of a given area.

\section{Table 1. A Typology of Supply and Demand Side Aspects and} Methods

\begin{tabular}{|c|c|}
\hline $\begin{array}{c}\text { Supply-side aspects: urban } \\
\text { renewal in neighbourhoods; } \\
\text { emphasis on production factors; } \\
\text { planning and property } \\
\text { development. }\end{array}$ & $\begin{array}{c}\text { Method: institutional analysis at } \\
\text { the neighbourhood level; case- } \\
\text { study involving qualitative } \\
\text { interviews, planning and } \\
\text { development protocols, } \\
\text { descriptive statistics, and maps; } \\
\text { comparative analysis of affected } \\
\text { and control group sales, } \\
\text { marketing brochures }\end{array}$ \\
\hline $\begin{array}{c}\text { Demand-side aspects: lifestyles } \\
\text { and urban housing preferences, } \\
\text { emphasis on consumption factors; } \\
\text { identification of geographically } \\
\text { specific tastes and preferences of } \\
\text { consumers. }\end{array}$ & $\begin{array}{c}\text { Method: nuanced and systematic } \\
\text { interviewing of residents and } \\
\text { professionals; document analysis } \\
\text { of marketing brochures and } \\
\text { popularised literature. }\end{array}$ \\
\hline
\end{tabular}

There are many different ways to approach a concrete objective such as urban micro-level property development. A commendable one is to combine qualitative and quantitative data and different techniques and methods to be able to cover the objectives: in this case, property development, neighbourhood change and urban regeneration.

\section{SUMMARY AND CONCLUSIONS}

Each section of this paper has picked an important element of urban sustainability. First that various economic and institutional drivers of property development can coexist. Secondly, in relation to the market, as neighbourhood attractiveness matters too many spatial issues are involved here such as the preferences and sociodemographic backgrounds of neighbourhood residents. Thirdly, urban renewal links the market-based property and the neighbourhood revitalisation agendas together. Lastly, when selecting a method for empirical research, while today the qualitative approach is increasingly gaining popularity, any quantification will inevitably increase the credibility of the evidence.

Throughout the review a multilevel approach that is sensitive to various market and policy influences has been championed. Essentially, property developments occur where positive changes in property value occur or are expected to occur. However, larger projects might also be dependent on government initiatives and interventions especially in an urban context. Outcomes in relation to property values and developments, neighbourhood dynamics and urban regenerations are possible to split into either supply or demand driven ones, and within each category, into either profitability or sustainability. Sustainability includes economic and social sustainability too - rather vague and contestable criteria that point to the long-term reinvestment in neighbourhood amenities. To be able to tease out significant evidence about the nature of any kinds 
of sustainability evaluation of the property development project or neighbourhood change we need nuanced research methods. Such analytical tools may be designed based on a systematic collection of information about area-level property development outcomes and processes. What kinds of management structures do the projects have in terms of private, public and voluntary sector participation? Are their outcomes meant to be sustainable, and if so with respect to which dimension? Is the area being upgraded in its entirety or does the project result in islands? And so forth.

\section{GLOSSARY}

Externalities - unintended localised effects of an action which is intended as beneficial for the community/society; either negative or positive ones.

Gentrification - upgrading of a (traditional) working-class neighbourhood.

Green - the environmental-ecologic dimension (i.e. the traditional definition) of sustainable development, such as energy efficiency, renewable energy and emissions.

Institutional parameters - formal and informal norms that constitute the boundaries for human behaviour, socioeconomic processes, management practices and so forth.

Neighbourhood dynamics - increase or decrease (or no change) in the quality or change in the character of an urban residential area.

Neighbourhood revitalisation - improvement of a derelict or illperforming neighbourhood through a coordinated framework of investment, (re)development and management.

The New Economy; the knowledge economy - the sectors of the economy driven by ICT.

New urbanism; Neo-traditionalism - design approach aimed at imitating the traditional European city; emphasis on human scale, aesthetic architecture, and the provision of public space and transport; 'small-is-beautiful' as a guiding principle.

Public-private-partnership (PPP) - a common way of implementing urban renewal or property development projects is to combine the resources of the private (seeks new possibilities for investment) and public sector (lacks funds).

Sustainable development - according to the 'Brundtland report' (1987) "development that meets the needs of the present without compromising the ability of future generations to meet their own needs;" has ecologic-environmental, social-cultural, and economic-financial dimensions.

Urban regeneration; urban renewal - orchestrated efforts to improve the appearance of a predefined part of the city.

\section{REFERENCES}

[1] Song Y, Knaap G-J. Measuring the effects of mixed land uses on housing values. Reg Sci Urban Econ 2004; 34: 663-80.

[2] Morrow-Jones HA, Irwin EG, Roe B. Consumer preference for neotraditional neighbourhood characteristics. Housing Policy Debate 2004; 15(1): 171-202.

[3] Bryson JR, Daniels PW, Warf B. Service worlds. People, organisations, technologies. London: Routledge 2004.
[4] Bryson JR, Lombardi R. Balancing product and process sustainability against business profitability: sustainability as a competitive strategy in the property development process. Business Strategy and the Environment 2009; 18(2): 97-107.

[5] Gyourko J, Saiz A. Reinvestment in the housing stock: the role of construction costs and the supply side. J Urban Econ 2004; 55(2): 238-56.

[6] Bramley G. The impact of land use planning and tax subsidies on the supply and price of housing in Britain. Urban Stud 1993; 30(1): 5-13.

[7] Pogodzinsky JM, Sass TR. The economic theory of zoning: a critical review. Land Econ 1990; 66(3): 294-314.

[8] Pogodzinsky JM, Sass TR. Measuring the effects of municipal zoning regulations: a survey. Urban Stud 1991; 28(4): 597-621.

[9] Guy S, Henneberry J. Understanding urban development processes: integrating the economic and the social in property research, Urban Stud 2000; 37(13): 2399-416.

[10] Doak J, Karadimitriou N. (Re) development, complexity and networks: a framework for research. Urban Stud 2007; 44(2): 20929.

[11] Kauko T. Sign value, topophilia and the locational component in property prices. Environ Plan A 2004; 36: 859-78.

[12] Kozlowski M, Huston S. Influence of urban design master plans on property sub-markets: two case studies in Brisbane. Int J Housing Mark Anal 2008; 1(3): 214-30.

[13] Levin EJ, Wright R E. Speculation in the housing market? Urban Stud 1997; 34(9): 1419-37.

[14] Oxley M, Golland A. Economic rent, residual value and the economics of affordable housing development. Paper presented at the European Real Estate Society Conference, Milan. June 2-5, 2004.

[15] Kauko T. Comparing spatial features of urban housing markets: Recent evidence of submarket formation in metropolitan Helsinki and Amsterdam. Delft: DUP Science Publication 2005.

[16] de Souza Briggs X. More Pluribus, less Unum? The changing geography of race and opportunity. In: Beider $\mathrm{H}$, Ed. Neighbourhood renewal \& housing markets. Community engagement in the US \& UK. Oxford: Blackwell 2007; pp. 63-87.

[17] Ferrari E, Lee P. Changing Spatial, Ethnic, and Tenure Patterns in England. In: Beider H, Ed. Neighbourhood renewal \& housing markets. Community engagement in the US \& UK. Oxford: Blackwell 2007; pp. 31-62.

[18] Townshend T. From inner city to inner suburb? Addressing housing aspirations in low demand areas in NewcastleGateshead, UK. Housing Studies 2006; 21(4): 501-21.

[19] Dökmeci V, Önder Z, Yavas A. External factors, housing values, and rents: evidence from survey data. J Housing Res 2003; 14(1): 83-99.

[20] Barber A, Groves R, Murie A. Changing housing markets, race and community: policy and practice in Birmingham. In: Beider H, Ed. Neighbourhood renewal \& housing markets. Community engagement in the US \& UK. Oxford: Blackwell 2007; pp. 115-37.

[21] Popkin SJ. Race and public housing transformation in the United States. In: Beider H, Ed. Neighbourhood renewal \& housing markets. Community engagement in the US \& UK. Oxford: Blackwell 2007; pp. 138-62.

[22] Nguyen MT. Does affordable housing detrimentally affect property values? A review of the literature. J Plann Lit 2005; 20(1): 15-26.

[23] Goodwin P. Manifesto for black urbanism. London: Centre for Urban and Community Research 2007.

[24] Smets P, Kreuk N. Together or Separate in the Neighbourhood? Contacts Between Natives and Turks in Amsterdam. Urban Stud 2008; 1: 35-47. Available at http://www.bentham.org/open/tousj/ openaccess $2 . h$ tm [accessed 7 may, 2010].

[25] Permentier M, Van Ham M, Bolt G. Same neighbourhood ... different views? A confrontation of internal and external neighbourhood reputations. Housing Studies 2008; 23(6): 833-55.

[26] Uuskallio I. Arvostetut asuinsijat. Asuntoalueiden arvostuksen sosiokulttuurinen analyysi 1900-luvun Helsingissä ja Tehtaankadulta etelään [in Finnish]. City of Helsinki Urban Facts Research series 2001; pp. 8.

[27] Ley D. Alternative explanations for inner-city gentrification: a Canadian assessment. Ann Assoc Am Geogr 1986; 76: 521-35.

[28] Robinson D. Living parallel lives? Housing, residential segregation and community cohesion in England. In: Beider H, Ed. 
Neighbourhood renewal \& housing markets. Community engagement in the US \& UK. Oxford: Blackwell 2007; pp. 163-85.

[29] Gram-Hanssen K, Bech-Danielsen C. House, home and identity from a consumption perspective. Housing, Theory and Society 2004; 21(1): 17-26.

[30] Ærø T. Residential choice from a lifestyle perspective. Housing, Theory and Society 2006; 23(2): 109-30.

[31] Bourdieu P. Distinction: A social critique of the judgement of taste. London: Routledge \& Kegan Paul 1984.

[32] Kauko T. The housing market dynamics of two Budapest neighbourhoods. Housing Studies 2009; 24(5), pp. 587-610.

[33] Scott A. Professor, UCLA, lecture "Reflections on the creative city: The example of Amsterdam", Amsterdam: AMIDSt (University of Amsterdam), April 2, 2006.

[34] Hamnett C. Unequal city. London in the global arena. London: Routledge 2003.

[35] Beider H. Towards a new policy agenda? In: Beider H, Ed. Neighbourhood renewal \& housing markets. Community engagement in the US \& UK. Oxford: Blackwell 2007; pp. 317-38.

[36] Smith DP, Butler T. Guest editorial. Environ Plan A 2007; 39: 2-9.

[37] Butler T. For gentrification? Environ Plan A 2007; 39: 162-81.

[38] Bounds M, Morris A. Second wave gentrification in inner-city Sydney. Cities 2006; 23 (2): 99-108.

[39] Immergluck D. Large redevelopment initiatives, housing values and gentrification: The case of the Atlanta beltline. Urban Stud 2009; 46(8): 1723-45

[40] Sullivan DM. Reassessing gentrification. Measuring residents' opinions using survey data. Urban Affairs Review 2007; 42(4): 583-92.

[41] Meen G, Andrew M. On the use of policy to reduce housing market segmentation. Reg Sci Urban Econ 2004; 34: 727-51.

[42] Lees L. A reappraisal of gentrification: towards a 'geography of gentrification'. Prog Hum Geogr 2000; 24(3): 389-408.

[43] Couch C. Urban regeneration in Liverpool. In: Couch C, Fraser C, Percy S, Eds. Urban regeneration in Europe. Oxford: Blackwell 2003; pp. 34-55.

[44] Couch C. Economic and physical influences on urban regeneration in Europe. In: Couch C, Fraser C, Percy S, Eds. Urban regeneration in Europe. Oxford: Blackwell 2003; pp. 166-79.

[45] Stead D, Hoppenbrouwer E. Promoting an urban renaissance in England and the Netherlands. Cities 2004; 21(2): 119-36.

[46] Weingaertner C, Barber ARG. Urban regeneration and sustainability: challenges for established small busineses. Paper presented at the ENHR conference, Rotterdam, June 25-28, 2007.

[47] Turcu C. In the quest of sustainable communities: a theoretical framework to assess the impact of urban regeneration on community sustainability. In: Tsenkova S, Ed. Planning strategies for sustainable cities. Calgary: University of Calgary Press 2009.

[48] Kauko T. From modelling tools towards the market itself - an opportunity for sustainability assessment? Int J Strat Property Manag 2008; 12, pp. 95-107.

[49] Julegina A, Cars G, Holt-Jensen A. Housing policies, path dependencies and present challenges. In: Holt-Jensen A, Pollock E,
Eds. Urban sustainability and governance: new challenges in Nordic-Baltic housing policies. New York: Nova Science Publishers 2009; pp. 13-29.

[50] Taşan-Kok T. Entrepreneurial governance: challenges of largescale property-led urban regeneration projects. Tijdschrift voor Economische en Sociale Geografie 2010; 101(2): 126-49.

[51] Van Beckhoven E, van Kempen R. Social effects of urban restructuring: a case study in Amsterdam and Utrecht, the Netherlands. Housing Studies 2003; 18(6): 853-75.

[52] Uitermark J, Duyvendak JW, Kleinhans R. Gentrification as a governmental strategy: social control and social cohesion in Hoogvliet, Rotterdam. Environ Plan A 2007; 39: 125-41.

[53] Kucharska-Stasiak E, Zaleczna M. Municipality as an owner of housing stock - a case of Lodz. Paper presented at the $15^{\text {th }}$ ERES Conference, Krakow June 18-21, 2008.

[54] Schmidt L. For tett? Fortetting, planprosess og bokvalitet I nye byboligprosjekter [in Norwegian]. NIBR-rapport 2007; pp. 12.

[55] Grant J. Mixed use in theory and practice: Canadian experience with implementing a planning principle. J Am Plann Assoc 2002; 68(1): 71-84.

[56] Deitrick S, Ellis C. New urbanism in the inner city: a case study of Pittsburgh. J Am Plann Assoc 2004; 70(4): 26-442.

[57] Beider H. Introduction. In: Beider H, Ed. Neighbourhood renewal \& housing markets. Community engagement in the US \& UK. Oxford: Blackwell 2007; pp.1-27.

[58] Southworth M. Walkable suburbs? An evaluation of neotraditional communities at the urban edge. J Am Plann Assoc 1997; 63(1): 28 44 .

[59] Atkinson R. The evidence on the impact of gentrification; new lessons for the urban renaissance? Eur J Housing Policy 2004; 4(1): 107-31.

[60] Schwegler B. Entrepreneurial governance and the urban restructuring of a Slovakian town. In: Tsenkova S, Nedović-Budić Z, Ed. The urban mosaic of post-socialist Europe. Space, institutions and policy. Heidelberg: Physica-Verlag 2006; pp. 295318.

[61] Arctander S. Developer's strategic use of urban design in Norwegian Brownfield- and waterfront developments: a pilot case study, in proceedings CIB W70 Changing user demands on buildings. Norway: Trondheim 2006.

[62] RICS. Financing and valuing sustainable property: we need to talk. Findings in Built and Rural Environments (FiBRE); RICS Research 2007; April. Available at http://www.rics.org/site/download feed aspx?fileID=3442\&fileExtension=PDF [accessed 7 May, 2010].

[63] D'Arcy E. Markets, market structures and market change: expanding the real estate research paradigm. Pacific Rim Property Res J 2006; 12(4): 446-65.

[64] Hull A. Evaluation in area-based regeneration: programme evaluation challenges. In: Miller D, Khakee A, Hull A, Woltjer J, Eds. New principles in planning evaluation. Aldershot: Ashgate 2008; pp. 185-200.

This is an open access article licensed under the terms of the Creative Commons Attribution Non-Commercial License (http://creativecommons.org/licenses/by$\mathrm{nc} / 3.0 /$ ) which permits unrestricted, non-commercial use, distribution and reproduction in any medium, provided the work is properly cited. 